\title{
Analisis Kemampuan Koneksi Matematis Siswa SMA Kelas XI dalam Menyelesaikan Soal Materi Pengaplikasian Kalkulus pada Turunan
}

\author{
Nurul Ramadhani Dwiwandira ${ }^{1}$, Ayu Tsurayya ${ }^{2}$ \\ ${ }^{1,2}$ Prodi Pendidikan Matematika, Fakultas Keguruan dan Ilmu Pendidikan, Universitas Muhammadiyah Prof. Dr. Hamka, \\ Jl. Tanah Merdeka No.20, Jakarta, Indonesia \\ nurulrdw17@gmail.com
}

\begin{abstract}
This research purposed to analyze the students' mathematical connection ability in problem solving in the application of calculus to derivatives. This type of research is descriptive qualitative research with the subjects of this study were being 35 students of class XI with a sampling technique using purpose sampling. The instrument used is a mathematical connection ability test and interviews. The result of indicate that from 35 students there are 6 students in the low mathematical connection ability category, 25 students in the medium mathematical connection ability category, and 4 students in the high mathematical connection ability category. From the amount of data, the mathematical connection ability tends to be in the medium category. In the low category, students often have difficulty understanding mathematical concepts, in the medium category they already understand mathematical concepts but still like to be less thorough. While the category is very good in understanding mathematical concepts.
\end{abstract}

Keywords: Connection Mathematical Ability, Calculus, Derrivative

\begin{abstract}
Abstrak
Tujuan penelitian ini untuk menganalisis kemampuan koneksi matematis siswa dalam menyelesaikan soal materi pengaplikasian kalkulus pada turunan. Jenis penelitian ini adalah penelitian deskriptif kualitatif dengan subjek penelitiannya adalah 35 siswa kelas XI dengan teknik sampling menggunakan purpose sampling. Instrumen yang digunakan berupa tes kemampuan koneksi matematis dan wawancara. Hasil dari penelitian ini menunjukkan bahwa dari 35 siswa terdapat 6 siswa dengan kemampuan koneksi matematis kategori rendah, 25 siswa dengan kemampuan koneksi matematis kategori sedang, dan 4 dengan kemampuan koneksi matematis kategori tinggi. Dari banyaknya data, kemampuan koneksi matematis cenderung berada pada kategori sedang. Pada kategori rendah, siswa sering mengalami kesulitan dalam memahami konsep matematika, pada kategori sedang sudah memahami konsep matematika tetapi masih suka kurang teliti. Sedangkan pada kategori sudah sangat baik dalam memahami konsep matematika.
\end{abstract}

Kata kunci: Kemampuan Koneksi Matematis, Kalkulus, Turunan

Copyright (c) 2021 Nurul Ramadhani Dwiwandira, Ayu Tsurayya

$\triangle$ Corresponding author: Ayu Tsurayya

Email Address: ayu.tsurayya@uhamka.ac.id (Jl. Tanah Merdeka No.20, Jakarta Timur-Kota Jakarta)

Received 16 July 2021, Accepted 27 July 2021, Published 08 August 2021

\section{PENDAHULUAN}

Matematika adalah ilmu yang dapat berguna dengan terus mengikuti perkembangan yang ada (Lestari, L., \& Surya, 2017). Karena, matematika ini adalah ilmu bidang yang sangat berkaitan antar topik satu dengan topik yang lainnya menurut (Nugraha, 2017). Dimana, ilmu matematika ini membahas secara logika dan penalaran manusia serta seringkali menjadi solusi pada ilmu lain (Trisnawati et al., 2018). Oleh karena itu, perlu dilakukannya pembelajaran matematika agar mampu meningkatkan kualitas dalam pemahaman siswa pada aktivitas sehari-hari.

Sesuai dengan tujuan dari matematika menurut (Agustina, 2016) adalah dapat mempersiapkan kemampuan kecerdasan, dan kemampuan keterampilan serta dapat membentuk kepribadian siswa. Namun, berdasarkan hasil data dari PISA (Programme for International Student Assessment) (OECD, 2019) ini 
Analisis Kemampuan Koneksi Matematis Siswa SMA Kelas XI dalam Menyelesaikan Soal Materi Pengaplikasian Kalkulus pada Turunan, Nurul Ramadhani Dwiwandira, Ayu Tsurayya

menunjukkan bahwa Indonesia mengalami penurunan terendah pada tahun 2018 yang diujicobakan pada 3 bidang. Salah satu bidang nya adalah kemampuan matematika.

Pada kemampuan matematika ini, matematika memiliki tujuan dari KTSP menurut (Wardhani, 2010) kemampuan matematika kemampuan siswa yang sangat diperlukan dalam menguasai soal konsep-konsep pada matematika. Dimana, agar siswa dapat menjelaskan hubungan antar konsep dan menginterpretasikan konsep secara luas, lengkap, dan tepat pada saat menyelesaikan masalah dalam matematika. Namun, faktanya koneksi matematis siswa di Indonesia masih pada kategori yang rendah.

Berdasarkan menurut (Bernard \& Senjayawati, 2019) mengatakan bahwa siswa masih terdapat dikategori yang rendah pada kemampuan dalam mengaitkan konsep pelajaran matematika. Hal ini dapat diperkuat dari penelitian (Warih et al., 2016), dimana siswa belum bisa menghubungkan antar konsep terutama pada materi sebelumnya yaitu Teorema Pythagoras sehingga ketika siswa menjawab soal itu mengalami kesulitan.

Pada penelitian ini, soal yang dibuat akan berdasarkan menurut (Ansori, 2020) indikator dalam menentukan kemampuan koneksi matematis. Konsep matematika yang berkaitan pada kehidupan seharihari banyak terdapat pada pelajaran yang berkaitan dengan kalkulus. Dimana menurut Leithold (Wahyuni, 2017) adalah mempelajari kalkulus ini berkaitan dengan trigonometri, aljabar, dan geometri pada sekolah menengah umum, untuk itu diperlukan adanya memahami konsep matematika. Kalkulus adalah cabang dari

Turunan merupakan salah satu cabang dari kalkulus menurut (Utari et al., 2019). Turunan ialah salah satu pelajaran yang banyak dikeluhkan para siswa baik kelas IPA maupun IPS pada sekolah menengah atas (SMA), karena masih ada yang belum memahami konsep dari pokok bahasan turunan. Oleh karena itu, dibutuhkan cara agar dapat memudahkan para siswa memahami turunan yaitu dengan cara menghubungkan soal kepada kehidupan sehari-hari menurut (Susanti, 2017). Berdasarkan pada penjelasan yang sudah dijelaskan di atas, sehingga peneliti tertarik untuk meneliti tentang kemampuan koneksi matematis siswa pada siswa SMA kelas XI dalam menyelesaikan soal materi pengaplikasian kalkulus pada turunan.

\section{METODE}

Jenis yang digunakan pada penelitian ini adalah deskriptif dengan pendekatan kualitaif. Penelitian kualitatif itu sendiri menurut (Bengtsson, 2016) adalah metode dalam membantu untuk memahami kondisi manusia dalam situasi dan persepsi yang berbeda. Tujuan utama penelitian kualitatif menurut (Gumilang, 2016) adalah untuk menyelidiki penemuan perbedaan yang terjadi dalam memperoleh lebih banyak data yang didapat pada tempat penelitian. Penelitian ini menggunakan instrumen dari indikator kemampuan koneksi matematis dan aspek yang diteliti dapat dilihat pada tabel sebagai berikut.

Tabel 1. Indikator Kemampuan Koneksi Matematis

\begin{tabular}{|c|l|}
\hline Nomor soal & \multicolumn{1}{|c|}{ Indikator konekasi matematis } \\
\hline 1,2 & Menggunakan hubungan antara topik matematika, \\
\hline 3,4 & Menggunakan konsep matematika di bidang lain \\
\hline 5,6 & Menggunakan konsep matematika yang berkaitan pada kehidupan sehari-hari \\
\hline
\end{tabular}

(Ansori, 2020) 
Penelitian dilakukan di kelas XI SMA pada tahun ajaran 2020/2021. Subjek penelitian dipilih menggunakan teknik purposive sampling yaitu pengambilan sampel dengan memenuhi kriteria dari kategori tes yang telah dikerjakan, kemudian dilanjutkan wawancara 6 siswa kelas XI dengan 2 subjek koneksi matematis siswa rendah, 2 subjek koneksi matematis sedang, dan 2 subjek koneksi matematis siswa tinggi. Kemudian dilanjutkan dengan wawancara secara semi terstruktur pada subjek penelitian mengenai tes yang sudah diselesaikan siswa akan diberikan skor. Tes yang sudah diselesaikan siswa akan diberikan skor pada. Peneliti menggunakan pedoman peskoran menurut (Suhandri et al., 2017) dapat dilihat di bawah ini.

Tabel 2. Kriteria Pedoman Penskoran Kemampuan Koneksi Matematis Siswa

\begin{tabular}{|c|l|}
\hline Skor & \multicolumn{1}{|c|}{ Kriteria Jawaban dan Alasan } \\
\hline 0 & Siswa tidak memberikan penjelasan jawaban. \\
\hline 1 & $\begin{array}{l}\text { Siwa mampu menjawab sebagian soal kemampuan koneksi ide-ide matematis, dan melakukan } \\
\text { banyak kesalahan dalam perhitungan. }\end{array}$ \\
\hline 2 & $\begin{array}{l}\text { Siwa mampu menjawab sebagian soal kemampuan koneksi ide-ide matematis, mengidentifikasi } \\
\text { unsur-unsur penting, namun banyak ide-ide yang keliru, melakukan beberapa kesalahan } \\
\text { perhitungan. }\end{array}$ \\
\hline 3 & $\begin{array}{l}\text { Siswa mampu menjawab soal kemampuan koneksi ide-ide matematis, mengidentifikasi unsur- } \\
\text { unsur penting secara benar, tetapi masih terdapat kesalahan. }\end{array}$ \\
\hline 4 & $\begin{array}{l}\text { Siswa mampu menjawab soal, kemampuan menjelaskan kembali ide-ide matematis secara } \\
\text { lengkap dan benar. }\end{array}$ \\
\hline
\end{tabular}

\section{HASIL DAN DISKUSI}

Berdasarkan hasil tes tulis 6 soal uraian pada materi Pengaplikasian Turunan yang sduah dikerjakan oleh 35 siswa SMA kelas XI diperoleh data kemampuan koneksi matematis seperti gambar di bawah ini.

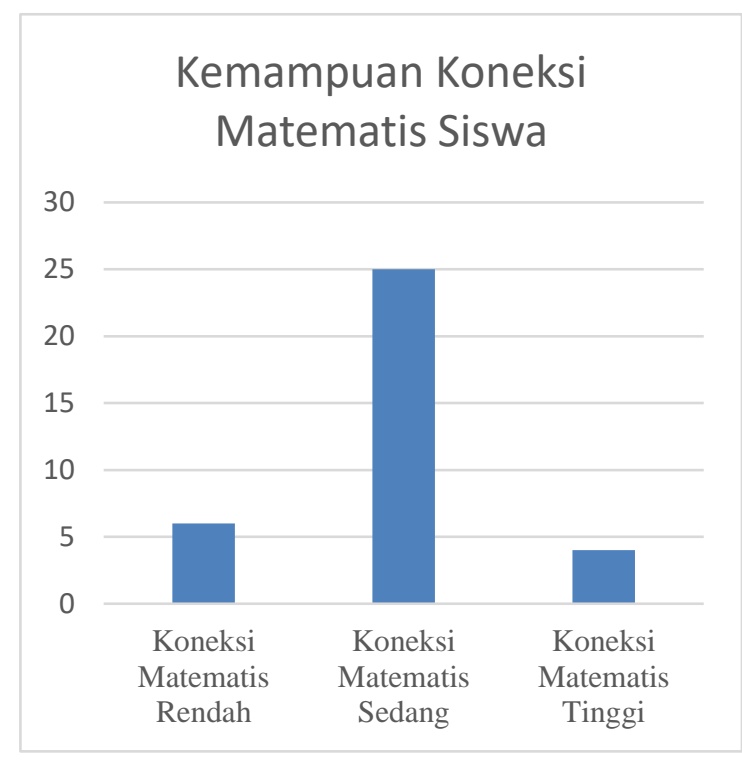

Gambar 1. Hasil dari Tes Tulis Kemampuan Koneksi Matematis Siswa

Berdasarkan gambar 1 diketahui bahwa terdapat 4 siswa dengan kategori kemampuan koneksi matematis tinggi, 25 siswa termasuk kategori sedang, dan 6 siswa termasuk kategori rendah. Subjek 
Analisis Kemampuan Koneksi Matematis Siswa SMA Kelas XI dalam Menyelesaikan Soal Materi Pengaplikasian Kalkulus pada Turunan, Nurul Ramadhani Dwiwandira, Ayu Tsurayya

penelitian yang terpilih adalah S1 dan S2 memiliki kemampuan koneksi matematis yang rendah, S3 dan S4 memiliki kemampuan koneksi matematis yang sedang, sedangkan S5 dan S6 memiliki kemampuan koneksi matematis yang tinggi.

Adapun soal untuk mendeskripsikan bagaimana kemampuan siswa dalam menginterpretasikan hubungan ide-ide matematika pada materi pengaplikasian kalkulus adalah sebagai berikut.

1. Sebuah taman berbentuk persegi panjang dengan keliling $(2 x+30)$ meter dan lebar $(9-x)$ meter. Agar luas taman maksimum, panjang taman tersebut adalah ... meter.

Gambar 2. Analisis pada Soal Nomor 1

Pada soal di atas, digunakan untuk mengetahui kemampuan koneksi matematis pada indikator 1 yaitu menggunakan hubungan antar topik matematika. Di bawah ini, akan disajikan hasil kemampuan koneksi matematis siswa dalam menyelesaikan soal nomor 1 pada pengaplikasian turunan berdasarkan indikator 1 .

\section{Kemampuan Koneksi Matematis Rendah}

$$
\begin{aligned}
& 1 \quad k=2(P+L) \\
& (2 x+30)=2((p+(9-x)) \\
& (2 x+30)=2 p+(18-2 x) \\
& 2 p=(2 x+30)-(18-2 x) \\
& 2 p=4 x+12 \\
& p=2 x+6
\end{aligned}
$$

Gambar 3. Hasil Tes Kemampuan Koneksi Matematis S1

$$
\begin{aligned}
& \text { Diketahui : } \text { keliling }=(2 x+30) \text { meter } \\
& \text { Lebar }=(5-x) \text { meter } \\
& \text { Ditany = Panjang taman } \\
& \text { Jawab: }
\end{aligned}
$$

Gambar 4. Hasil Tes Kemampuan Koneksi Matematis S2

\section{Subjek $S 1$}

Dilihat dari tes kemampuan koneksi matematis bahwa subjek S1 hampir memahami konsep, namun banyak ide-ide yang keliru dan melakukan beberapa kesalahan sehingga subjek S1 termasuk pada kemampuan koneksi matematis pada kategori rendah. Dapat dilihat pada jawaban subjek S1 tidak dapat melakukan penyelesaian yang tepat dan subjek kurang mampu mengungkapkan alur penyelesaiannya, hal ini terlihat dimana subjek mengalami kebingungan ketika ditanya materi yang digunakan pada soal tersebut. Hal tersebut diperkuat oleh hasil wawancara.

$\mathrm{N} \quad$ : Apa yang diketahui dari soal?

S1 : Karena diketahui di soal itu ada variabel, konstanta sama... apalagi ya, lupa, jadi saya mikirnya mungkin itu aljabar kak.

$\mathrm{N} \quad$ : Itu dari yang kamu jawab itu $\mathrm{p}=2 \mathrm{x}+6$, sudah selesai sampai situ aja?

S1 : Dari situ saya kira udah yang dicari dari persamaan $\mathrm{p}$ kak, bukan nilai dari $\mathrm{p}$ itu berapa kak. 
Dilihat dari tes kemampuan koneksi matematis bahwa subjek S2 kurang memahami konsep, karena tidak ada penjelasan jawaban sehingga subjek S1 termasuk pada kemampuan koneksi matematis pada kategori rendah. Dapat dilihat pada jawaban subjek S1 tidak menuliskan langkah penyelesaiannya, hal ini terlihat pada hanya menuliskan diketahui dan ditanya nya saja. Hal tersebut diperkuat oleh hasil wawancara.

$\mathrm{N} \quad$ : Apa yang diketahui dari soal?

S2 : Apa ya kak. Paling diketahui disitu kan ada keliling sama lebarnya kak. Cuman saya bingung pas melakukan perhitungannya kak. Jadi saya cuman bisa menulis diketahui dan ditanya saja.

$\mathrm{N} \quad$ : Jadi ngga kamu lanjutin dari yang diketahui itu?

S2 : Engga kak hehe saya kurang yakin juga saat ingin menyelesaikannya.

\section{Kemampuan Koneksi Matematis Sedang}

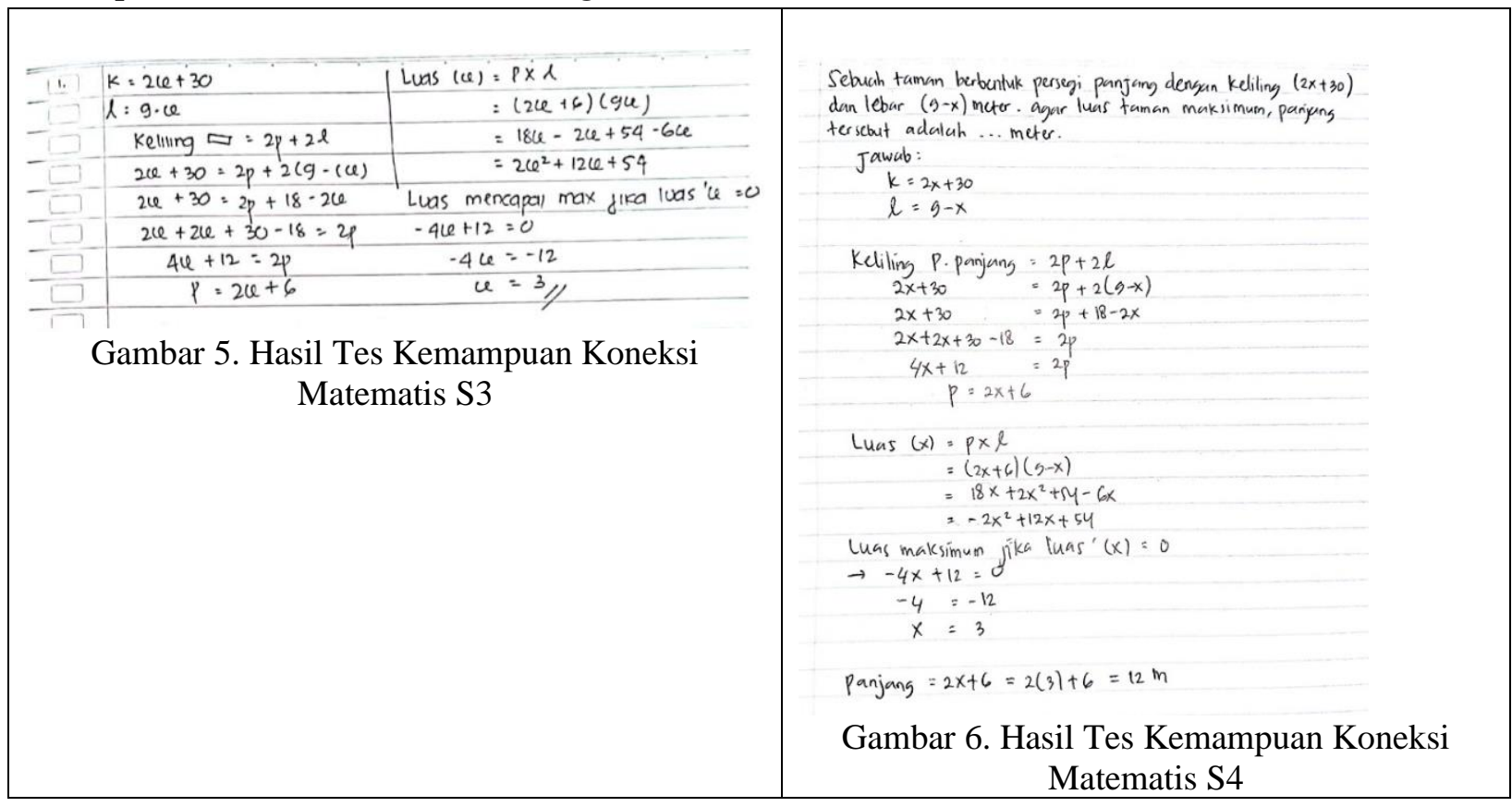

\section{Subjek $S 3$}

Dilihat dari tes kemampuan koneksi matematis bahwa subjek S3 sudah cukup dalam memahami konsep, tetapi ada beberapa kesalahan dalam menyelesaikan soal sehingga S3 termasuk kemampuan koneksi matematis pada kategori yang sedang. Dapat dilihat pada jawaban subjek S3 menuliskan langkah penyelesaiannya dengan kurang teliti dan kurang lengkap sesuai yang diminta pada soal. Hal tersebut diperkuat oleh hasil wawancara.

$\mathrm{N} \quad$ : Apa yang diketahui dari soal?

S3 : Kan lebarnya udah ketahuan, sama kelilingnya. Trus masukin nilai lebar ke rumus keliling, dihitung-hitung kan tuh dapet persamaan p. Abis itu masukin ke luas dan mencari nilai x dari luas maksimum.

$\mathrm{N} \quad$ : Lalu cukup sampe situ aja yang ditanyakan?

S3 : Iya kak. 
Analisis Kemampuan Koneksi Matematis Siswa SMA Kelas XI dalam Menyelesaikan Soal Materi Pengaplikasian Kalkulus pada Turunan, Nurul Ramadhani Dwiwandira, Ayu Tsurayya

\section{Subjek S4}

Dilihat dari tes kemampuan koneksi matematis bahwa subjek S4 sudah cukup dalam memahami konsep, tetapi ada beberapa kesalahan dalam menyelesaikan soal sehingga S4 termasuk pada kemampuan koneksi matematis pada kategori yang sedang. Dapat dilihat pada jawaban subjek S4 menuliskan langkah penyelesaiannya dengan kurang teliti walaupun hasilnya sudah benar. Hal tersebut diperkuat oleh hasil wawancara.

$\mathrm{N} \quad$ : Apa yang diketahui dari soal?

S4 : Kan diketahui lebarnya dan keliling nya

$\mathrm{N} \quad$ : Lalu apa yang ditanya?

S4 : Yang ditanya persamaan pada panjangnya kak.

\section{Kemampuan Koneksi Matematis Tinggi}

1. $K=2 u+30 \rightarrow 2 p+2 e$

$2 u+30=2(\rho+l)$

$2 u+30=2(p+(g-u))$

$2 u+30=2 p+18-2 u$

$4 u+12=2 p$

Gambar 7. Hasil Tes Kemampuan Koneksi

Matematis S5

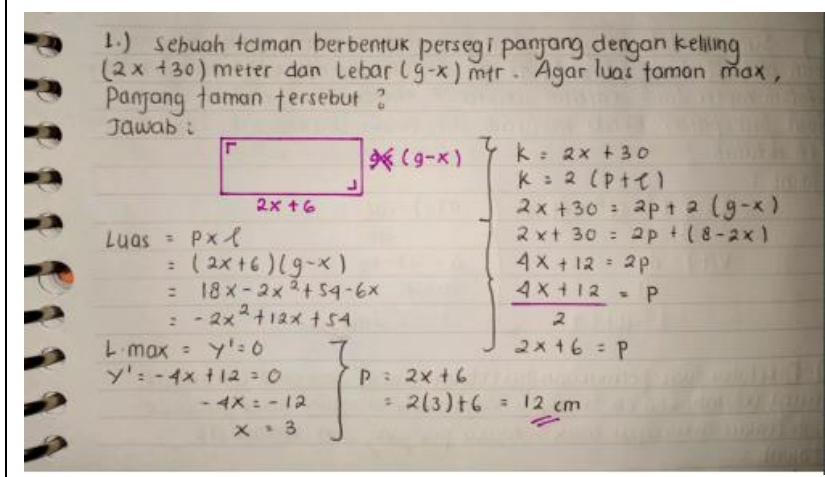

Gambar 8. Hasil Tes Kemampuan Koneksi Matematis S6

\section{Subjek S5}

Dilihat dari tes kemampuan koneksi matematis bahwa subjek S5 sudah cukup baik dalam memahami konsep. Dapat dilihat dari jawaban subjek S5 yang mengerjakan dengan cara yang kurang lengkap. Namun subjek S5 ini mampu menjelaskan kembali langkah demi langkah pengerjaan secara detail nya, sehingga S5 termasuk pada kemampuan koneksi matematis pada kategori tinggi. Hal tersebut diperkuat oleh hasil wawancara.

$\mathrm{N} \quad$ : Apa yang diketahui dari soal?

S5 : Kan diketahui kelilingnya itu $2 x+30$, dan kelilingnya itu kan $2 p+21$, yaudah tinggal lebarnya dimasukin dan disatuin deh. Terus saya pas ngerjain lupa kalau ini kan materi turunan, tapi saya ngga sampai ke materi tersebut.

$\mathrm{N} \quad$ : Lalu menurutmu apa yang kurang langkah dalam mengerjakan itu?

S5 : Sehabis dari langkah mendapat persamaan, langkah selanjutnya mencari persamaan luas dan kemudian diturunkan persamaan tersebut didapat nilai $\mathrm{x}$. Baru dimasukkan hasil nilai $\mathrm{x}$ ke persamaan panjangnya. 


\section{Subjek S6}

Dilihat dari tes kemampuan koneksi matematis bahwa subjek S6 sangat baik dalam memahami konsep yang digunakan dan solusi yang yang didapatkannya mengarahkan pada penyelesaian yang tepat sehingga S6 termasuk pada kemampuan koneksi matematis pada kategori tinggi. Berdasarkan jawaban subjek S6 yang menuliskan langkah penyelesaiannya dengan lengkap dan detail. Hal tersebut diperkuat oleh hasil wawancara.

$\mathrm{N} \quad$ : Apa yang diketahui dari soal?

S6 : Saya memahaminya lihat soal kan udah terdapat kelilingnya walaupun belum

sebenarnya, dan terdapat lebarnya juga kan. Jadi tinggal hitung luas taman maksimalnya gitu.

$\mathrm{N} \quad$ : Lalu menurutmu sehabis itu ada lagi ngga langkah selanjutnya? Apa cukup sampe disitu aja?

S6 : Masih ada, nanti abis dapet nilai $\mathrm{x}$ dari luas maksimal, masukin ke persamaan pada $\mathrm{p}$ nya deh,

Berikut ini adalah hasil analisis kemampuan koneksi matematis yang diperkuat dengan data wawancara.

Tabel 3. Hasil Wawancara dengan Subjek S1 dan S2

\begin{tabular}{|c|c|c|}
\hline \multirow{2}{*}{ Indikator } & \multicolumn{2}{|c|}{ Kemampuan Koneksi Matematis Rendah } \\
\hline & S1 & S2 \\
\hline 1 & $\begin{array}{l}\text { Subjek S1 belum mampu menyelesaikan } \\
\text { pada nomor } 2 . \quad \text { Berdasarkan hasil } \\
\text { wawancara, subjek S1 berkata bahwa kurang } \\
\text { mengerti dalam mengerjakannya. }\end{array}$ & $\begin{array}{l}\text { Subjek S2 sudah mampu menyelesaikan } \\
\text { pada nomor } 2 . \quad \text { Berdasarkan hasil } \\
\text { wawancara, subjek S2 mampu memaparkan } \\
\text { hasil proses pengerjaannya. }\end{array}$ \\
\hline 2 & $\begin{array}{l}\text { Subjek S1 belum mampu menyelesaikan } \\
\text { kedua pertanyaan dari soal yang ditanyakan. } \\
\text { Dimana berdasarkan hasil wawancara, } \\
\text { subjek S1 mengaku tidak mengerti semua } \\
\text { dari yang ditanyakan maupun diketahui } \\
\text { harus dilakukan penyelesaian seperti apa. } \\
\text { Namun subjek S1 ini mengetahui materi } \\
\text { yang dibahas pada soal tersebut adalah } \\
\text { berhubungan dengan topik pada bidang lain. }\end{array}$ & $\begin{array}{l}\text { Subjek S2 mampu menyelesaikan } \\
\text { permasalahan pada nomor } 3 \text { dengan benar } \\
\text { dan lengkap. Namun, subjek S2 belum } \\
\text { mampu menyelesaikan pada nomor } 4 . \\
\text { Begitpun saat wawancara, subjek S2 } \\
\text { menyebutkan konsep dengan baik pada } \\
\text { nomor } 3 \text { dari setiap langkah yang dikerjakan } \\
\text { dan sedangkan pada nomor } 4 \text { ini mengalami } \\
\text { kesulitan memahami maksud yang } \\
\text { ditanyakan. Tetapi subjek S2 menyebutkan } \\
\text { bahwa materi yang dibahas pada soal } \\
\text { tersebut adalah berhubungan dengan topik } \\
\text { lain. }\end{array}$ \\
\hline 3 & $\begin{array}{l}\text { Subjek S1 belum mampu menyelesaikan } \\
\text { kedua pertanyaan dari soal yang ditanyakan. } \\
\text { Dimana berdasarkan hasil wawancara, } \\
\text { subjek S1 mengaku tidak mengerti semua } \\
\text { dari yang ditanyakan maupun diketahui } \\
\text { harus dilakukan penyelesaian seperti } \\
\text { apa. Namun, subjek S1 ini mengetahui } \\
\text { materi yang dibahas pada soal tersebut } \\
\text { adalah berhubungan dengan topik pada } \\
\text { kehidupan sehari-hari pada nomor } 6 \text { yaitu } \\
\text { contohnya pada pengusaha. }\end{array}$ & $\begin{array}{l}\text { Subjek S2 belum mampu menyelesaikan } \\
\text { kedua pertanyaan dari soal yang ditanyakan. } \\
\text { Dimana berdasarkan hasil wawancara, } \\
\text { subjek S1 mengaku tidak mengerti semua } \\
\text { dari yang ditanyakan maupun diketahui. } \\
\text { Namun, subjek S2 ini mengetahui materi } \\
\text { yang dibahas pada soal tersebut adalah } \\
\text { berhubungan dengan topik pada kehidupan } \\
\text { sehari-hari pada nomor } 6 \text { yaitu contohnya } \\
\text { pada bidang ekonomi. }\end{array}$ \\
\hline
\end{tabular}




\begin{tabular}{|c|c|c|}
\hline \multirow{2}{*}{ Indikator } & \multicolumn{2}{|c|}{ Kemampuan Koneksi Matematis Sedang } \\
\hline & S3 & S4 \\
\hline 1 & $\begin{array}{l}\text { Subjek S3 sudah cukup mampu } \\
\text { menyelesaikan pada nomor 2. Namun, } \\
\text { berdasarkan hasil wawancara, subjek S3 } \\
\text { berkata bahwa bertukar jawaban dengan } \\
\text { temennya pada saat mengerjakan tetapi } \\
\text { masih ingat materi yang disampaikan. }\end{array}$ & $\begin{array}{l}\text { Subjek S4 sudah mampu menyelesaikan } \\
\text { pada nomor } 2 \text { tetapi terdapat banyak } \\
\text { kesalahan saat mengerjakan. Berdasarkan } \\
\text { hasil wawancara, subjek S4 dapat } \\
\text { menerangkan hasil jawabannya tetapi tidak } \\
\text { menyadari letak kesalahannya. }\end{array}$ \\
\hline 2 & $\begin{array}{l}\text { Subjek S3 belum mampu menyelesaikan } \\
\text { kedua pertanyaan dari soal yang ditanyakan. } \\
\text { Dimana berdasarkan hasil wawancara, } \\
\text { subjek S3 mengaku tidak terlalu mengerti } \\
\text { langkah dalam penyelesaiannnya jadi subjek } \\
\text { S3 bertanya kepada teman. Namun, masih } \\
\text { ingat materi yang digunakan seperti soal } \\
\text { fisika. }\end{array}$ & $\begin{array}{l}\text { Subjek S4 mampu menyelesaikan pada soal } \\
\text { nomor } 3 \text { namun masih kurang teliti. } \\
\text { Sedangkan subjek S4 belum mampu } \\
\text { menyelesaikan soal nomor } 4 \text { karena kurang } \\
\text { teliti dan terdapat beberapa kesalahan dalam } \\
\text { mengerjakannya. Berdasarkan wawancara, } \\
\text { subjek S4 memahami hubungan antar } \\
\text { konsep pada matematika. }\end{array}$ \\
\hline 3 & $\begin{array}{l}\text { Subjek S3 belum mampu menyelesaikan } \\
\text { kedua pertanyaan dari soal yang ditanyakan. } \\
\text { Dimana berdasarkan hasil wawancara, } \\
\text { subjek S3 mengaku tidak terlalu mengerti } \\
\text { langkah dalam penyelesaiannnya jadi subjek } \\
\text { S3 bertanya kepada teman. Namun, masih } \\
\text { memahami nomor } 6 \text { ini berkaitan dengan } \\
\text { kehidupan sehari-hari. }\end{array}$ & $\begin{array}{l}\text { Subjek S4 belum mampu menyelesaikan } \\
\text { kedua pertanyaan dari soal yang ditanyakan, } \\
\text { dikarenakan kurang teliti dan terdapat } \\
\text { beberapa kesalahan dalam mengerjakannya. } \\
\text { Berdasarkan wawancara, subjek S4 } \\
\text { memahami bahwa nomor } 6 \text { ini sangat } \\
\text { berkaitan dengan aktivitas setiap hari }\end{array}$ \\
\hline
\end{tabular}

\begin{tabular}{|c|c|c|}
\hline \multirow{2}{*}{ Indikator } & \multicolumn{2}{|c|}{ Kemampuan Koneksi Matematis Tinggi } \\
\hline & S5 & S6 \\
\hline 1 & $\begin{array}{l}\text { Subjek S5 sudah cukup mampu } \\
\text { menyelesaikan pada nomor } 2 \text { tetapi masih } \\
\text { terdapat langkah yang kurang dalam } \\
\text { pengerjaannya. Berdasarkan hasil } \\
\text { wawancara, subjek S5 dapat menjelaskan } \\
\text { kembali dengan baik. }\end{array}$ & $\begin{array}{l}\text { Subjek S6 sudah mampu menyelesaikan } \\
\text { pada nomor } 2 \text { dengan baik dan lengkap. } \\
\text { Berdasarkan hasil wawancara, subjek subjek } \\
\text { S6 pun dapat menjelaskan kembali dengan } \\
\text { baik. }\end{array}$ \\
\hline 2 & $\begin{array}{l}\text { Subjek S5 mampu menyelesaikan kedua } \\
\text { pertanyaan dari soal yang ditanyakan karena } \\
\text { menjawab dengan teliti dan lengkap. } \\
\text { Berdasarkan hasil wawancara, subjek S5 } \\
\text { dapat menjelaskan kembali langkah demi } \\
\text { langkah dan mengatakan "Ini konsep } \\
\text { kecepatan dan turunan fisika, yang } \\
\text { digunakan pada turunan matematika". }\end{array}$ & $\begin{array}{l}\text { Subjek S6 mampu menyelesaikan kedua } \\
\text { pertanyaan dari soal yang ditanyakan karena } \\
\text { menjawab dengan teliti dan lengkap. } \\
\text { Berdasarkan hasil wawancara, subjek S5 } \\
\text { dapat menjelaskan kembali langkah demi } \\
\text { langkah dan mengatakan "Saat mengerjakan } \\
\text { sih kemarin kepikiran ini rumus fisika yang } \\
\text { gerak benda itu". }\end{array}$ \\
\hline 3 & $\begin{array}{l}\text { Subjek S5 mampu menyelesaikan kedua } \\
\text { pertanyaan dari soal yang ditanyakan karena } \\
\text { menjawab dengan teliti dan lengkap. } \\
\text { Berdasarkan hasil wawancara, subjek S5 } \\
\text { dapat menjelaskan kembali langkah demi } \\
\text { langkah hingga dapat menjelaskan } \\
\text { menggunakan gambar pada soal nomor } 5 \\
\text { dan memahami konsep ini sangat berkaitan } \\
\text { dengan aktivitas setiap hari }\end{array}$ & $\begin{array}{l}\text { Subjek S5 mampu menyelesaikan nomor } 5 \\
\text { dengan baik, namun pada nomor } 6 \text { terdapat } \\
\text { kesalahan. Berdasarkan hasil wawancara, } \\
\text { subjek S6 dapat menjelaskan kembali } \\
\text { langkah demi langkah hingga dapat } \\
\text { menjelaskan menggunakan gambar pada } \\
\text { soal nomor } 5 \text { dan memahami konsep ini } \\
\text { sangat berkaitan dengan aktivitas setiap hari. }\end{array}$ \\
\hline
\end{tabular}


Berdasarkan yang sudah dijelaskan di atas, terlihat bahwa kedua subjek dari kemampuan koneksi matematis tinggi mampu mencapai indikator dari Ansori. Lalu untuk kedua subjek dari kemampuan koneksi matematis sedang beberapa soal mencapai indikator dari Ansori. Sedangkan untuk kedua subjek dari kemampuan koneksi matematis rendah belum mampu memenuhi indikator dari Ansori dan cenderung mudah putus asa dalam mengerjakan soal yang diberikan.

\section{KESIMPULAN}

Berdasarkan hasil penelitian dari 35 siswa dibagi menjadi 3 kategori, dimana terdapat 6 siswa dengan kategori kemampuan koneksi matematis rendah, 25 siswa dengan kategori kemampuan koneksi matematis sedang, dan 4 siswa dengan kategori kemampuan koneksi matematis tinggi. Dari 3 kategori tersebut, masing-masing siswa tersebut memiliki kemampuan koneksi matematis yang berbeda-beda dalam mengerjakan soal, yaitu (1) Pada kemampuan koneksi matematis yang rendah menunjukkan bahwa subjek S1 dan S2 memiliki banyak permasalahan dalam menerjemahkan yang dimaksud pada soal sehingga seringkali mereka mengalami kesulitan dalam mengerjakannya. (2) Pada kemampuan koneksi matematis yang sedang menunjukkan bahwa subjek S3 dan S4 ini sudah cukup mengerti dalam memahami konsep matematika pada soal namun seringkali mereka kurang teliti dalam mengerjakan langkah demi langkah tersebut. (3) Pada kemampuan koneksi matematis yang tinggi menunjukkan bahwa subjek S5 dan S6 sangat memahami konsep matematika pada soal cerita ini, sehingga mereka terkadang menjelaskan maksud dari soal tersebut melalui gambar kemudian dilanjutkan dengan pemahaman konsep yang mereka pahami.

\section{UCAPAN TERIMA KASIH}

Saya mengucapkan terima kasih kepada seluruh Dosen Pendidikan Matematika Universitas Muhammadiyah Prof. Dr. HAMKA (UHAMKA) terutama pada Ibu Ayu Tsurayya, S.Pd., M.Si. selaku dosen pembimbing yang telah memberikan arahan pada proses pembuatan artikel ini. Serta ucapan terima kasih ditunjukkan kepada orang tua dan para teman-teman yang telah men-support selama penelitian.

\section{REFERENSI}

Agustina, L. (2016). Upaya Meningkatkan Kemampuan Pemahaman Konsep dan Pemecahan Masalah Matematika Siswa SMP Negeri 4 Sipirok Kelas VII Melalui Pendekatan Matematika Realistik (PMR). EKSAKTA : Jurnal Penelitian Dan Pembelajaran MIPA, 1(1), 1-7. http://jurnal.umtapsel.ac.id/index.php/eksakta/article/view/49

Ansori, A. (2020). Analisis kemampuan resiliensi dalam meningkatkan kemampuan koneksi matematis siswa. Jurnal Pembelajaran Matematika Inovatif, 3(4), 353-362. https://doi.org/10.22460/jpmi.v3i4.353-362

Bengtsson, M. (2016). How to plan and perform a qualitative study using content analysis. NursingPlus Open, 2, 8-14. https://doi.org/10.1016/j.npls.2016.01.001

Bernard, M., \& Senjayawati, E. (2019). Meningkatkan Kemampuan Koneksi Matematik Siswa SMP dengan 
Menggunakan Pendekatan Metaphorical Thinking Berbantuan Software Geogebra. Jurnal Mercumatika: Jurnal Penelitian Matematika Dan Pendidikan Matematika, 3(2), 79-87. https://doi.org/10.26486/jm.v3i2.558

Gumilang, G. S. (2016). Metode Penelitian Kualitatif dalam Bidang Bimbingan dan Konseling. Jurnal Fokus Konseling, 2(2). http://ejournal.stkipmpringsewu-lpg.ac.id/index.php/fokus/a

Lestari, L., \& Surya, E. (2017). The Effectiveness of Realistic Mathematics Education Approach on Ability of Students ' Mathematical Concept Understanding. International Journal of Sciences: Basic and Applied Research (IJSBAR), 34(1), 91-100. http://gssrr.org

Nugraha, A. A. (2017). Analisis koneksi matematis siswa pada materi SPLDV. Suska Journal of Mathematics Education, 3(2), 130. https://doi.org/10.24014/sjme.v3i2.3897

OECD. (2019). PISA 2018 Results. Combined Executive Summaries. Journal of Chemical Information and Modeling, 53(9), 1689-1699.

Suhandri, S., Nufus, H., \& Nurdin, E. (2017). Profil Kemampuan Koneksi Matematis Mahasiswa dalam Menyelesaikan Masalah Matematika Berdasarkan Level Kemampuan Akademik. Jurnal Analisa, 3(2), 115-129. https://doi.org/10.15575/ja.v3i2.2012

Susanti, E. (2017). Penerapan Model Pembelajaran Probing-Prompting Untuk Meningkatkan Kemampuan Berpikir Kritis Matematis Siswa Kelas XI.IPA MAN 1 Kota Bengkulu. Jurnal Pendidikan Matematika Raflesia, 2(1), 1-107.

Trisnawati, Anggraini, R. S., \& Fauzan, A. (2018). The Influence Of Realistic Mathematics Education (RME) Approach On Students' Mathematical Communication Ability. Malikussaleh Journal of Mathematics Learning (MJML), 1(1), 31-35. https://doi.org/10.2991/icm2e-18.2018.48

Utari, K., Rahma, F. L., \& Ali, S. (2019). Aplikasi Geogebra pada Pembelajaran Kalkulus. 1, 418-423.

Wahyuni, A. (2017). Analisis Hambatan Belajar Mahasiswa Pada Mata Kuliah Kalkulus Dasar. JNPM (Jurnal Nasional Pendidikan Matematika), 1(1), 10. https://doi.org/10.33603/jnpm.v1i1.253

Wardhani, S. (2010). Implikasi Karakteristik Matematika dalam Pencapaian Tujuan Mata Pelajaran Matematika Di SMP/MTs. Yogyakarta: Depdiknas PPPPTK.

Warih, P. D., Parta, I. N., \& Rahardjo, S. (2016). Analisis Kemampuan Koneksi Matematis Siswa Kelas VIII Pada Materi Teorema Pythagoras. Prosiding Konferensi Nasional Penelitian Matematika Dan Pembelajarannya [KNPMP I] Universitas Muhammadiyah Surakarta, Malang: Universitas Negeri Malang, 377-384. 